\title{
Effects of inoculum potential on screening for resistance to Plasmodiophora brassicae in greenhouse trials
}

\author{
JÓZEF ROBAK* and R. L. GABRIELSON** \\ *Research Institute of Vegetable Crops, 96-100 Skierniewice, Poland \\ **Western Washington Research and Extension Center, Puyallup, WA 98371 USA
}

(Received: March 16, 1987)

\begin{abstract}
Several factors, including growth medium, inoculum density, and inoculum storage affected the reaction of resistant and susceptible Brassicas to Plasmodiophora brassicae in the greenhouse. A high level of disease was achieved using Peat-litte mix $\mathrm{R}$ and a commercial greenhouse mix. There was little difference in disease incidence when spore suspensions were pipeted into planting holes or when seedlings were dipped into spore suspensions. Seedlings transplanted from sand or Petri dishes gave higher levels of disease than direct seeding. Two-year frozen storage of clubs reduced the inoculum potential to a level unable to define resistance. Inoculum levels of $10^{3-7}$ spores per $\mathrm{ml}$ from fresh clubs, or $10^{5-7}$ spores per $\mathrm{ml}$ from clubs frozen for 2 or 4 years, produced $90 \%$ club incidence of susceptible cauliflower and Chinese cabbage. A concentration of only $10^{6-8}$ spores per $\mathrm{ml}$ from fresh clubs was required for maximum disease expression in a cauliflower line partially resistant to clubroot.
\end{abstract}

\section{INTRODUCTION}

One of the biggest problems in evaluating Brassica lines for resistance to clubroot disease (Plasmodiophora brassicae Wor.) has been the inconsistency of results from test to test and between investigators. There is considerable variation in the techniques used by clubroot workers to evaluate seedlings for resistance to P. brassicae (Dix on, 1976; Lewis and Brokenshire, 1977).

Reported here are the effects of growth media, inoculation techniques, spore concentration, and long-term frozen storage of clubs (resting spores) on severity of clubroot disease in resistant and susceptible Brassicas.

\section{MATERIALS AND METHODS}

Experiments were conducted in a greenhouse with air temperatures of 21 to $24^{\circ} \mathrm{C}$ days and 17 to $18^{\circ} \mathrm{C}$ nights. Daylight was supplemented with cool white fluorescent light to provide a $14 \mathrm{~h}$ light perıod per $24 \mathrm{~h}$. The following Brassica 
lines were used: 1) resistant line-WA-WI cauliflower, a breeding line deriving clubroot resistance from Badger Shipper cabbage; 2) susceptible lines - cauliflower, var. Monarch 73; cauliflower var. Snowball; and a hybrid Chinese cabbage var. unknown. Resting spore suspensions for inoculation were obtained by macerating clubs in water and straining the macerate through four to six layers of cheesecloth. Spore concentrations were adjusted to about $10^{8}$ spores per $\mathrm{ml}$ or diluted to the levels designated. Clubs were collected from infected cabbage and Chinese cabbage grown in the field in western Washington. Clubs were used either fresh or frozen. Frozen clubs were stored in plastic bags in a freezer maintained at about $-25^{\circ} \mathrm{C}$. Refrozen samples were subjected to five cycles of $24 \mathrm{~h}$ freezing and $24 \mathrm{~h}$ thawing. Unless they are designated as frozen, spores were obtained from fresh clubs. Unless otherwise noted, plastic pots $(7 \times 7 \times 7 \mathrm{~cm})$ filled with moistened Peat-lite mix. R (Boodley and Sheldrake, 1963) (W. R. Grace and Co., Cambridge, MA 02140) with a $\mathrm{CaCl}_{2} \mathrm{pH}$ of 5.2. were used. Four or five holes were punched into this medium in each pot. One $\mathrm{ml}$ of spore suspension was pipetted into each hole and seeds were planted directly into this. There were 6 pots (24-30 plants) for each experimental variable. Growth media were kept saturated for the first three weeks by daily watering, with less water for the field loam soil where saturation promoted damping off. Clubroot symptoms were recorded after 5 to 6 weeks. All plants with definite clubs were recorded as infected. The data reported in Tables 1 and 2 are from one experiment each. The data in Table 3 are combined from 2 experiments.

In two experiments the effects of several steam pasteurized growth media on disease expression were measured. These media included: a field soil; Sultan silt loam; fine-silty; mixed nonacid; Mesic aquic xerofluvent (used both steam pasteurized $\left(\mathrm{CaCl}_{2} \mathrm{pH} 5.1\right)$ and naturally infested with $P$. brassicae $\left(\mathrm{CaCl}_{2} \mathrm{pH}\right.$ 5.2); a poorly drained Schalcar muck (Teric Medisprits) $\mathrm{CaCl}_{2} \mathrm{pH}$ 5.0; this muck soil mixed 1:1 with Sunshine sphagnum peat moss (Western Peat Moss Ltd., Voncouver, Canada V52 lkl) $\mathrm{CaCl}_{2} \mathrm{pH} 4$.6; a commercial greenhouse mix

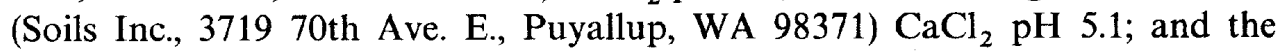
Peat-lite mix R. inoculation techniques were also compared in one of these trials. Seven days old seedlings germinated in sand or on filter paper were dipped momentarily into a spore suspension before transplanting, or transplanted into holes in which one $\mathrm{ml}$ of spore suspension had been pipetted, to compare with the standard direct seeded suspension technique.

\section{RESULTS}

Inoculations in Peat-lite mix $\mathbf{R}$ and the commercial greenhouse mix resulted in the most consistent clubroot disease (Table 1). In these mixes there were no consistent differences between transplanting or direct seeding, between dipping or slurry or inoculation methods, or between transplanting from sand or Petri dishes (Table 1). 
Table 1

Percentage clubroot disease in resistant WA-WI and susceptible Monarch 73 cauliflower following different methods of seeding and inoculation in several growth media compared with that in naturally infested field soil

\begin{tabular}{|c|c|c|c|c|c|c|c|c|c|c|}
\hline \multirow{3}{*}{$\begin{array}{l}\text { Inoculation method } \\
\text { Growth media/Hosts }\end{array}$} & \multicolumn{4}{|c|}{ Transplant from sand } & \multicolumn{4}{|c|}{ Transplant from Petri dish } & \multirow{2}{*}{\multicolumn{2}{|c|}{$\frac{\text { Direct sow }}{\text { suspension }}$}} \\
\hline & \multicolumn{2}{|c|}{ dipping } & \multicolumn{2}{|c|}{ suspension } & \multicolumn{2}{|c|}{ dipping } & \multicolumn{2}{|c|}{ suspension } & & \\
\hline & res. & susc. & res. & susc. & res. & susc. & res. & susc. & res. & susc. \\
\hline Muck soil & $0^{2}$ & 67 & $0^{\mathbf{a}}$ & 94 & $0^{\mathrm{a}}$ & 96 & $16^{\mathrm{b}}$ & 37 & $26^{\mathrm{bc}}$ & 75 \\
\hline Muck soil + peat & & & & & & & & & & \\
\hline $\begin{array}{l}\text { moss } 1: 1 \\
\text { Peat-lite mix } \mathrm{R}\end{array}$ & $\begin{array}{l}80^{\mathrm{e}} \\
92^{\mathrm{fg}}\end{array}$ & $\begin{array}{l}100 \\
100\end{array}$ & $\begin{array}{r}56^{\mathrm{a}} \\
100^{\mathrm{h}}\end{array}$ & $\begin{array}{l}100 \\
100\end{array}$ & $\begin{array}{r}88^{\mathrm{et}} \\
100^{\mathrm{h}}\end{array}$ & $\begin{array}{l}100 \\
100\end{array}$ & $\begin{array}{l}55^{\mathrm{a}} \\
96^{\mathrm{g}}\end{array}$ & $\begin{array}{r}88 \\
100\end{array}$ & $\begin{array}{r}33^{2} \\
92^{f g}\end{array}$ & $\begin{array}{l}100 \\
100\end{array}$ \\
\hline Commercial greenhouse mix & $100^{\mathrm{h}}$ & 100 & $100^{\mathrm{h}}$ & 100 & $100^{\mathrm{h}}$ & 100 & $100^{\mathrm{h}}$ & 100 & $89^{\text {ef }}$ & 100 \\
\hline Sterilized field soil & $88^{\mathrm{ef}}$ & 100 & $83^{d}$ & 100 & $21^{\mathrm{b}}$ & 67 & $83^{\text {ef }}$ & 100 & $45^{\mathrm{d}}$ & 100 \\
\hline Naturally infested field soil & $52^{d}$ & 100 & & & $15^{b}$ & 56 & & & $15^{\mathrm{b}}$ & 30 \\
\hline
\end{tabular}

Values in each column not followed by the same letter differ significantly by the Student Multiple Range Test at $P=0.05$. 
Table 2

Percentage clubroot disease in resistant WA-WI and susceptible Snowball cauliflower following inoculation of seedlings with a spore suspension of different

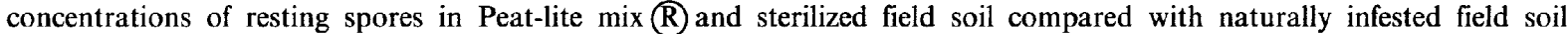

\begin{tabular}{|c|c|c|c|c|}
\hline \multirow{2}{*}{ No. spores per ml } & \multicolumn{2}{|c|}{ Peat-lite $\operatorname{mix} \mathbb{R}$} & \multicolumn{2}{|c|}{ Sterilized field soil } \\
\hline & resistant & susceptible & resistant & susceptible \\
\hline $10^{2}$ & $9^{\mathrm{b}}$ & 100 & $0^{\mathrm{a}}$ & 48 \\
\hline $10^{3}$ & $23^{\mathrm{cd}}$ & 100 & $8^{b}$ & 100 \\
\hline $10^{4}$ & $32^{\mathrm{d}}$ & 100 & $13^{\text {bc }}$ & 100 \\
\hline $10^{5}$ & $58^{\mathrm{ef}}$ & 100 & $19^{\mathrm{bed}}$ & 100 \\
\hline $10^{6}$ & $52^{\mathrm{e}}$ & 100 & $16^{\mathrm{bc}}$ & 100 \\
\hline $10^{7}$ & $70^{\mathrm{f}}$ & 100 & $23^{\text {cd }}$ & 100 \\
\hline $10^{8}$ & $69^{f}$ & 100 & $29^{\mathrm{cd}}$ & 100 \\
\hline Naturally infested field soil & - & - & $12.5^{\mathrm{bcd}}$ & 80 \\
\hline
\end{tabular}

Values in each column not followed by the same letter differ significantly by the Student Multiple Range Test at $P=0.05$. 
Table 3

Percentage clubroot disease in resistant WA-WI cauliflower and susceptible Chinese cabbage following inoculation with different concentrations of pathotype PB7 resting spores taken from fresh clubs. Frozen clubs stored for varing periods, and clubs that were refrozen and thawed five times before use

\begin{tabular}{|c|c|c|c|c|c|c|c|c|c|c|c|c|}
\hline \multirow{2}{*}{$\frac{\text { No. spores } / \mathrm{ml}}{\text { Source of spores }}$} & \multicolumn{2}{|c|}{$10^{2}$} & \multicolumn{2}{|c|}{$10^{3}$} & \multicolumn{2}{|c|}{$10^{4}$} & \multicolumn{2}{|c|}{$10^{5}$} & \multicolumn{2}{|c|}{$10^{6}$} & \multicolumn{2}{|c|}{$10^{7}$} \\
\hline & susc. & res. & susc. & res. & susc. & res. & susc. & res. & susc. & res. & susc. & res. \\
\hline 1981 clubs fresh & $82^{\text {no }}$ & $0^{a}$ & $93^{\mathrm{pq}}$ & $33^{\mathrm{g}}$ & $100^{r}$ & $58^{\mathrm{ij}}$ & $100^{r}$ & $62^{k}$ & $100^{r}$ & $82^{\text {no }}$ & $100^{r}$ & $86^{\circ}$ \\
\hline 1981 clubs refrozen & $58^{\mathrm{ij}}$ & $0^{\mathrm{a}}$ & $60^{i j}$ & $5^{b}$ & $92^{\mathrm{p}}$ & $28^{\mathrm{gf}}$ & $100^{r}$ & $33^{\mathrm{g}}$ & $100^{r}$ & $85^{\circ}$ & $100^{r}$ & $78^{m n}$ \\
\hline 1979 clubs frozen & $52^{i}$ & $0^{\mathrm{a}}$ & $75^{\mathrm{Im}}$ & $0^{\mathrm{a}}$ & $85^{\circ}$ & $17^{\mathrm{e}}$ & $94^{q}$ & $15^{\mathrm{e}}$ & $100^{r}$ & $7^{\mathrm{bc}}$ & $100^{r}$ & $34^{\mathrm{g}}$ \\
\hline 1979 clubs refrozen & $44^{\mathrm{h}}$ & $0^{\mathrm{a}}$ & $76^{\mathrm{m}}$ & $0^{\mathrm{a}}$ & $61^{j}$ & $30^{\mathrm{fg}}$ & $100^{r}$ & $6^{\mathrm{b}}$ & $100^{r}$ & $10^{\mathrm{dc}}$ & $100^{r}$ & $15^{\mathrm{e}}$ \\
\hline 1977 clubs frozen & $59^{\mathrm{ij}}$ & $0^{\text {a }}$ & $69^{k !}$ & $0^{\mathrm{a}}$ & $78^{\mathrm{mn}}$ & $18^{\mathrm{e}}$ & $99^{r}$ & $9^{\mathrm{bc}}$ & $100^{r}$ & $7^{\mathrm{bc}}$ & $100^{r}$ & $7^{\mathrm{bc}}$ \\
\hline 1977 clubs refrozen & $56^{\mathrm{ij}}$ & $0^{\mathrm{a}}$ & $83^{\text {no }}$ & $0^{\mathrm{a}}$ & $76^{\mathrm{m}}$ & $14^{\text {ed }}$ & $100^{r}$ & $18^{\mathfrak{e}}$ & $100^{r}$ & $23^{f}$ & $100^{r}$ & $46^{\mathrm{h}}$ \\
\hline
\end{tabular}

Values in each column not followed by the same letter differ significantly by the Student Multiple Range Test at $P=0.05$. 
Clubroot disease observed in naturally infested field soil was that observed following inoculations in greenhouse mixes at high inoculum levels (Tables 1 and 2). In Peat-lite mix $R$ heavy clubbing followed inoculation of susceptible cauliflower (Table 2) and Chinese cabbage (Table 3) with resting spores taken from fresh clubs at $10^{2}$ spores per $\mathrm{ml}$, while high levels of infection of a resistant cauliflower breeding line did not occur until spore concentrations of $10^{7-8}$ (Table 2) or $10^{6-7}$ (Table 3) were used.

Although high levels of disease were observed on susceptible cauliflower inoculated at $10^{3}$ spores per $\mathrm{ml}$ in sterile field soil, disease was consistently less in the resistant cauliflower breeding line inoculated in sterile field soil than in Peat-lite mix $\mathrm{R}$ at all spore concentrations (Table 2). Resting spores at $10^{7}$ spores per ml taken from clubs frozen for either 2 or 4 years produced only low levels of clubbing on a resistant cauliflower line, although they continued to heavily infect Chinese cabbage (Table 3). A cycle of refreezing and thawing reduced the infectivity of resting spores taken from fresh clubs, but had no observable affects on disease when inoculated at $10^{6-7}$ spores per $\mathrm{ml}$. Refreezing and thawing had no consistent effects on resting spores taken from clubs frozen for 2 or 4 years.

\section{DISCUSSION}

It is important to devise screening methods that minimize the chances of susceptible "escapes" being incorporated into breeding lines. This can be accomplished by maximizing inoculum potential confirming the observation of Lewis and Brohenshire (1977).

The effects of inoculum potential and inoculation methods on susceptible varieties of Brassica oleracea have been summarized by Colhoun (1958), Karling (1968) and Nowicki (1973). No attempt was made here to compare all these methods. The goal was to develop methods which would give consistent results that could be used to predict field performance of resistant germ plasm.

Although the muck soil used in this experiment was not suitable, Robak (1981) found that a muck soil from Rekowo, Poland was the best growth media tested for his greenhouse experiments. High levels of disease were achieved using Peat-lite mix R.

The mix or its ingredients are widely available (Cornell Peat-lite $\mathbf{R}$ Bulletin). It can provide a standard to evaluate the suitability of locally available soils or mixes. It is difficult to maintain the high moisture levels necessary for infection in mineral soils in the greenhouse. Further, non-pasteurized field soil, high moisture levels favor other pathogens (Monteith, 1924), damping off and wirestem disease, which interfere with clubroot symptom development.

Although the data here show no consistent advantage of the suspension method over the dipping method, Robak (1981) observed more consistent 
results with the suspension method. Furthermore, if large populations are screened there is the possibility of inoculum dilution problems with dippirig. Transplanting requires more labor than direct seeding, but tests only germinated seed and therefore reduces the amount of inoculum necessary. Petri dish germination is less timeconsuming than the sand method and saves more weak germinating seedlings.

Preservation of resting spores in frozen clubs is a common practice (Dixon, 1976). Lewis and Brokenshire (1977) noted a reduction in infectivity following 6 months frozen storage. In these trials frozen storage for two years reduced inoculum potential to a level unable to define resistance.

It was not known at the time these trials were conducted that the resistance of the WA-WI cauliflower line was temperature sensitive, breaking down at $20^{\circ} \mathrm{C}$ (Robak and $\mathrm{Gabrielson}$, unpublished).

Partial resistance was apparently operating here and it is obvious that inoculum levels, and an environment adequate to produce $100 \%$ clubroot infection in susceptible hosts, did not necessarily lead to maximum disease expression in this line. Jones and Ingram (1982) have also noted this using the European Clubroot Differential (ECD) set. Although the WA-WI line has been quite resistant in field trials (6\% clubbing in 1981), in 1982 it was $95 \%$ infected.

In both years, paired Chinese cabbage was $100 \%$ infected. The potential for breakdown of resistance of the WA-WI cauliflower line was predicted in greenhouse and growth chamber trials before it was observed in the field.

Resistance to clubroot in the WA-WI cauliflower line is temperature sensitive, being resistant at $15^{\circ} \mathrm{C}$ and susceptible at $20^{\circ} \mathrm{C}$ at high inoculation potentials (Robak and Gabrielson, unpublished). It is obvious from these results that there is a partial resistance at lower inoculum potentials. Only extensive field testing will determine if the field resistance derived from Badger Shipper germ plasm will be useful in areas where pathotype 7 is present.

\section{REFERENCES}

Boodley J. W., Sheldrake R., Jr., 1963. Artificial soil for commercial plant growing. Cornell Ext. Bull. 1104. 8 pp.

Colhoun J., 1958. Clubroot disease of crucifers caused by Plasmodiophora brassicae. Woron. A. monograph. Phytopath. Paper N. 3. The Commonwealth Mycol. Inst. Kew. Surrey, England.

Dix on G. R., 1976. Methods used in western Europe and the USA for testing Brassica seedling resistance to clubroot Plasmodiophora brassicae. Plant Path. 25: 129-134.

Karling J. S., 1968. The Plasmodiophorales. Hafner Publishing Co., NY.

Jones D. R., Ingram D. S., 1982. Factors affecting tests for differential pathogenicity in populations of Plasmodiophora brassicae Wor. Plant Pathl. 31: 229-238.

Lewis S. J., Brokenshire T., 1977. A comparison of plant inoculation techniques for the determination of Plasmodiophora populations. Proc.Woronin + 100 Conf., Univ. of Wisconsin, Madison: $54-67$. 
Monteith J., Jr., 1924. Relation of soil tempcrature and soil moisture to infection by Plasmodiophora brassicae. J. Agr. Res. 28: 549-562.

Nowicki B., 1973. Wybrane zagadnienia z biologii grzyba Plasmodiophora brassicae Wor. Acta. Agrobot., 26: $205-212$.

Robak J., 1981. Występowanie kiły kapusty na glebach torfowych oraz jej zwalczanie metodami chemicznymi. (Incidence of clubroot on muck soil and its chemical control). Ph. D. Thesis. Warsaw Agricultural University. $146 \mathrm{pp}$.

\section{Czynniki wpływające na odporność roślin krzyżowych na kiłę kapusty (Plasmodiophora brassicae)}

\section{Streszczenie}

Badano kilka czynników mających wpływ na odporność roślin krzyżowych na kiłę kapusty w warunkach szklarnianych takich jak: rodzaj substratu, zagęszczenie inokulum grzyba, metody inokulacji oraz długotrwałe przechowywanie inokulum grzyba w niskich temperaturach.

Najwyższy stopień porażenia uzyskano przy stosowaniu substratu torfowego Peat-Lite mix $\mathrm{R}$ oraz mieszanki torfowej $\mathrm{z}$ perlitem (torf niski + wysoki z domieszką perlitu). Stwierdzono niewielką różnicę $w$ procencie porażonych roślin testowych między zanurzaniem siewek w roztworze inokulumn a dozowaniem inokulum w otworki przed sadzeniem siewek. Stwierdzono jednocześnie wyższe porażenie testowanych roślin przy inokulacji siewek uzyskiwanych zarówno z wysiewu nasion do piasku, jak i na szalki Petriego aniżeli przy bezpośrednim wysiewie nasion do zainfekowanego podłoża. Przechowywanie próbek inokulum grzyba $w$ postaci narośli korzeniowych w niskich temperaturach $\left(-15^{\circ} \mathrm{C}\right)$ przez okres $2-4$ lat miało ujemny wpływ na żywotność zarodników przetrwalnikowych, co utrudniało określenie stopnia odporności testowanych roślin. Stwierdzono, że inokulacja całkowicie wrażliwych na kilę roślin kontrolnych zarodnikami pochodzącymi zarówno ze świeżych narośli korzeniowych lub przechowywanych przez okres 2 - 4 lat $w$ temperaturze $-15^{\circ} \mathrm{C}$ o zagęszczeniu $10^{3-7}$ zarodników na $1 \mathrm{ml}$ wywołała jednolicie wysoką infekcję roślin w granicach powyżej $90 \%$.

Do wywołania podobnych objawów porażenia na roślinach częściowo odpornych na kiłę należało użyć inokulum grzyba o zagęszczeniu $10^{6-8}$ zarodników na $1 \mathrm{ml}$ pochodzących ze świeżych narośli korzeniowych. 